\title{
Laparoscopic versus open surgery: aerosols and their implications for surgery during the COVID-19 pandemic
}

\author{
Janso P. Joseph (D) Anokha O. Joseph (D) - Susmita Oomman (iD · Naga V. G. Jayanthi $(\mathbb{D}$
}

Received: 4 May 2020 / Accepted: 19 May 2020 / Published online: 10 June 2020

(c) Springer-Verlag GmbH Austria, part of Springer Nature 2020

\section{Background}

In the past weeks, surgical guidelines in response to the COVID-19 pandemic have been read, disseminated and compared with gravitas. These include guidelines of the American College of Surgeons (ACS) [1], the four surgical royal colleges of the United Kingdom and Ireland (Royal College of Surgeons, RCS) [2], the Society of American Gastrointestinal and Endoscopic Surgeons (SAGES) [3], the Royal Australasian College of Surgeons (RACS) [4] and the European Society of Surgical Oncology (ESSO) [5]. The first three bodies cautioned regarding the potential for viral transmission during the use of laparoscopy, but based this recommendation on caution, not data. The RACS, in contrast, has advised that there is no evidence to suggest that laparoscopy puts surgical staff at a higher risk of viral transmission than open surgery. ESSO has not taken a specific stance on this issue. The recommendations cautioning against laparoscopy have significant implications for the practice of modern abdominal surgery, where laparoscopy is often an established, preferred and superior modality for operating. This is particularly the case for emergency gastrointestinal (GI) surgery and surgical

J. P. Joseph, MSc, MEd, FRCS (凶) • N. V. G. Jayanthi, MD, FRCS

Essex Upper GI, Regional Centre for Oesophago-Gastric Surgery, Broomfield Hospital, Court Road, Chelmsford, CM1 7ET, United Kingdom

janso.joseph@gmail.com

A. O. Joseph, MSc (Med Ed), MRCS

Department of General Surgery, North Middlesex Hospital, London, United Kingdom

S. Oomman, MD, FRCA

Department of Anaesthetics, Withybush General Hospital, Haverfordwest, United Kingdom oncology, domains which surgeons around the world are attempting to preserve despite the COVID-19 pandemic. In the authors' centres in the United Kingdom, there has been anecdotal avoidance of laparoscopy surgery based on the above guidelines.

\section{Aerosol-generating procedures}

An aerosol-generating procedure (AGP) is one that results in the production of airborne particles (also known as aerosols) [6]. All surgery-open and laparoscopic-is aerosol generating. Aerosols theoretically cause a problem because cells, bacterial particles and viral particles have been shown to be present in aerosols created by surgery. Aerosols are emitted when using electrocautery, high-speed tools, suction/ irrigation, in surgical smoke and on release of pneumoperitoneum [7, 8]. A review on surgical smoke concluded that the most effective strategy to decrease smoke inhalation is through evacuation near the point of smoke production and that there is no evidence that infections can be transmitted to humans through surgical smoke [9]. The theoretical concern about laparoscopic surgery appears to be an environmental viremia significant enough to cause healthcare staff infection at the point of release of pneumoperitoneum. Despite the ubiquity of laparoscopic surgery worldwide, and accepting the exceptional virulence of COVID-19, we could not locate any reports linking laparoscopic surgery directly to AGP-related infection.

\section{Current practice: China and Italy}

Considering the most recent experience in China and Italy during this pandemic, laparoscopy is still in use $[10,11]$. These surgeons are approaching surgery with caution, suggesting the use of dedicated COVID-19 operating rooms equipped with negative-pressure air- 
flow, appropriate decontamination, minimal staff, decreased electrocautery power settings, smoke extraction filters, careful deflation of pneumoperitoneum and, critically, the use of personal protective equipment (PPE). There have been no reported cases of surgical staff infection attributed to aerosols - though we appreciate that even a single case would be one too many.

\section{Laparoscopy or open surgery? PPE is key}

An operation (be it open or laparoscopic) should not be considered an isolated event in a patient's illness. The surgical approach has significant ramifications on the patient's journey, including postoperative pain and length of stay. A laparoscopic approach is frequently the standard of care, particularly in emergency GI surgery and surgical oncology. During this pandemic it is critical to reduce the length of stay in hospital, as we otherwise increase the risk of inhospital transmission to COVID-negative patients and transmissions from COVID-positive patients. The choice of operative approach should be determined by the team's familiarity with the procedure and with attention paid to known patient outcomes. Guidelines cautioning laparoscopic surgery should not give us a false sense of security about the safety of open surgery; regardless of the surgical approach taken, PPE is the key mitigator of risk when operating on patients with COVID-19.

\section{Conclusion}

There is no reasonable evidence to suggest that laparoscopy will place surgical teams at a higher risk of COVID-19 infection than open surgery. The RCS, ACS and SAGES guidelines that warn about the potential for viral transmission during laparoscopy are based on a dearth of data and an extreme amount of caution. During this global healthcare crisis, protecting healthcare staff from infection must be an utmost priority. In surgical specialties this can be achieved through a variety of techniques, including the provision and appropriate use of PPE. Given the lack of evidence regarding transmission of infection through aerosolization in laparoscopic surgery, the surgical approach should be based on surgical expertise and due consideration of established patient outcomes.

Author Contribution All authors contributed to the letter conception and writing. The first draft of the manuscript was written by Janso Padickakudi Joseph and all authors commented on previous versions of the manuscript. All authors read and approved the final manuscript.

Conflict of interest J.P. Joseph, A.O. Joseph, S. Oomman, and N.V.G. Jayanthi declare that they have no competing interests.

\section{References}

1. American College of Surgeons. COVID-19: considerations for optimum surgeon protection before, during, and after operation. 2020 March 27.. https://www.facs.org/-/ media/files/covid19/considerations_optimum_surgeon_ protection.ashx. Accessed 29 Mar 2020.

2. Intercollegiate General Surgery Guidance on COVID-19 Update. 2020 March 27; accessed on 29/03/2020. Available at: https://www.rcsed.ac.uk/news-public-affairs/news/ 2020/march/intercollegiate-general-surgery-guidanceon- covid-19-update

3. Society of American Gastrointestinal and Endoscopic Surgeons, European Association for Endoscopy Surgery. SAGES and EAES recommendations regarding surgical response to COVID-19 crisis. 2020 March 19. 2020. https:/ / www.sages.org/recommendations-surgicalresponse-covid-19/. Accessed 2 Apr 2020.

4. Royal Australasian College of Surgeons. RACS update on COVID-19. 2020 March 30.. https://mailchi.mp/surgeons/ racs- covid19-update-326517? $=81 \mathrm{e} 1 \mathrm{~d} 44 \mathrm{a} 55$. Accessed 2 Apr 2020.

5. European Surgical Society. Statement on COVID-19. 2020 March 27.. https://www.essoweb.org/news/essostatement-covid-19/. Accessed 4 May 2020.

6. Boswell C, Longstaff J, Infection Control Team. Health protection Scotland. 2019 November.. https:// hpspubsrepo.blob.core.windows.net/hps-website/nss/ 2893/documents/1_tbp-lr-agp-v1.pdf. Accessed 29 Mar 2020.

7. Kwak HD, Kim SH, Seo YS, Song KJ. Detecting hepatitis $B$ virus in surgical smoke emitted during laparoscopic surgery. Occup Environ Med. 2016;73(12):857-63.

8. YehHC, Turner RS, Jones RK, Muggenburg BA, LundgrenDL, Smith JP. Characterization of aerosols produced during surgical procedures in hospitals. Aerosol Sci Technol. 1995;22(2):151-61.

9. Sanderson C. Surgical smoke. J Perioper Pract. 2012;22(4): 122-8.

10. Zheng MH, Boni L, Fingerhut A. Minimally invasive surgery and the novel coronavirus outbreak: lessons learned in China and Italy. Ann Surg. 2020; https://doi.org/10.1097/ sla.0000000000003924.

11. Spinelli A, Pellino G. COVID-19 pandemic: perspectives on an unfolding crisis. Br J Surg. 2020; https://doi.org/10. $1002 /$ bjs.11627.

Publisher's Note Springer Nature remains neutral with regard to jurisdictional claims in published maps and institutional affiliations. 